\title{
Surface Chemistry Controls Magnetism in Cobalt
}

\section{Nanoclusters}

Michael J. Hartmann, ${ }^{\dagger}$ Jill E. Millstone ${ }^{\dagger *}$ and Hannu Häkkinen, ${ }^{+*}$

†Department of Chemistry, University of Pittsburgh, Pittsburgh, Pennsylvania 15260,

United States

$\ddagger$ Department of Physics and Chemistry, Nanoscience Center, University of Jyväskylä, FI40014 Jyväskylä, Finland

*Hannu Häkkinen, hannu.j.hakkinen@jyu.fi, *Jill Millstone, jem210@pitt.edu 
Table S1. Various starting local magnetic moments (LMMs) used to initiate single point calculation for bare $\mathrm{Co}_{13}$ cluster and final total magnetic moment (TMM) on the cluster.

\begin{tabular}{cc}
\hline $\begin{array}{c}\text { Initial LMM }\left(\mu_{\mathrm{B}} /\right. \\
\text { atom })\end{array}$ & Calculated TMM $\left(\mu_{\mathrm{B}}\right)$ \\
\hline 0.1 & 30.92 \\
\hline 1.0 & 30.92 \\
\hline 1.5 & 30.92 \\
\hline 2.0 & 30.92 \\
\hline 2.5 & 30.92 \\
\hline
\end{tabular}

Table S2. Total magnetic moments of each system calculated with GPAW and QE.

\begin{tabular}{ccc}
\hline System & $\begin{array}{c}\text { TMM with GPAW } \\
\left(\mu_{\mathrm{B}}\right)\end{array}$ & TMM with QE $\left(\mu_{\mathrm{B}}\right)$ \\
\hline $\mathrm{Co}_{13}($ Bare cluster $)$ & 30.9 & 31.0 \\
\hline $\mathrm{Co}_{13}\left(\mathrm{PH}_{3}\right)_{12}$ & 21.0 & 21.0 \\
\hline $\mathrm{Co}_{13}\left(\mathrm{PH}_{3}\right)_{9} \mathrm{Cl}_{3}$ & 24.0 & 24.0 \\
\hline $\mathrm{Co}_{13}\left(\mathrm{PH}_{3}\right)_{6} \mathrm{Cl}_{6}$ & 27.0 & 27.0 \\
\hline $\mathrm{Co}_{13}\left(\mathrm{PH}_{3}\right)_{3} \mathrm{Cl}_{9}$ & 29.8 & 29.9 \\
\hline $\mathrm{Co}_{13} \mathrm{Cl}_{12}$ & 29.7 & 29.7 \\
\hline $\mathrm{Co}_{13} \mathrm{~F}_{12}$ & 31.1 & 31.2 \\
\hline $\mathrm{Co}_{13} \mathrm{Br}_{12}$ & 27.8 & 27.8 \\
\hline $\mathrm{Co}_{13}\left(\mathrm{OH}_{12}\right.$ & 28.9 & 29.0 \\
\hline $\mathrm{Co}_{13}\left(\mathrm{CO}_{12}\right.$ & 20.2 & 20.7 \\
\hline $\mathrm{Co}_{13}\left(\mathrm{NH}_{3}\right)_{12}$ & 22.6 & 21.0 \\
\hline $\mathrm{Co}_{13}\left(\mathrm{PCl}_{3}\right)_{12}$ & 21.0 & \\
\hline
\end{tabular}


Table S3. Average bond length for three different bonds and angle formed between center Co-surface Co-ligand head group atoms in each cluster with a $\mathrm{Co}_{13}$ core.

\begin{tabular}{|c|c|c|c|c|}
\hline System & $\begin{array}{c}\text { Center - } \\
\text { Surface BL (A) }\end{array}$ & $\begin{array}{c}\text { Surface - } \\
\text { Surface BL (A) }\end{array}$ & $\begin{array}{c}\text { Surface - } \\
\text { Ligand BL (A) }\end{array}$ & $\begin{array}{l}\text { Co-Co-Ligano } \\
\text { angle }\left({ }^{\circ}\right)\end{array}$ \\
\hline $\mathrm{Co}_{13}$ & 2.34 & 2.46 & - & - \\
\hline $\mathrm{Co}_{13}\left(\mathrm{PH}_{3}\right)_{12}$ & 2.35 & 2.48 & 2.20 & 172 \\
\hline $\mathrm{Co}_{13}\left(\mathrm{PH}_{3}\right)_{9} \mathrm{Cl}_{3}$ & 2.35 & 2.48 & 2.21 & 172 \\
\hline $\mathrm{Co}_{13}\left(\mathrm{PH}_{3}\right)_{6} \mathrm{Cl}_{6}$ & 2.36 & 2.48 & 2.20 & 171 \\
\hline $\mathrm{Co}_{13}\left(\mathrm{PH}_{3}\right)_{3} \mathrm{Cl}_{9}$ & 2.36 & 2.48 & 2.16 & 170 \\
\hline $\mathrm{Co}_{13} \mathrm{Cl}_{12}$ & 2.36 & 2.48 & 2.07 & 175 \\
\hline $\mathrm{Co}_{13} \mathrm{~F}_{12}$ & 2.37 & 2.49 & 1.74 & 172 \\
\hline $\mathrm{Co}_{13} \mathrm{Br}_{12}$ & 2.35 & 2.47 & 2.21 & 176 \\
\hline $\mathrm{Co}_{13}(\mathrm{OH})_{12}$ & 2.35 & 2.48 & 1.77 & 167 \\
\hline $\mathrm{Co}_{13}(\mathrm{CO})_{12}$ & 2.37 & 2.50 & 1.81 & 174 \\
\hline $\mathrm{Co}_{13}\left(\mathrm{NH}_{3}\right)_{12}$ & 2.35 & 2.48 & 2.08 & 174 \\
\hline $\mathrm{Co}_{13}\left(\mathrm{PCl}_{3}\right)_{12}$ & 2.37 & 2.55 & 2.20 & 171 \\
\hline
\end{tabular}

\section{Ligand binding energy}

The ligand binding energy (LBE) of each $\mathrm{Co}_{\mathrm{N}}(\mathrm{N}=13$ or 55) cluster was calculated using the following equation.

$$
L B E=E\left[C o_{\mathrm{N}}(L i g)_{\mathrm{M}}\right]-\left(E\left[C o_{\mathrm{N}}\right]+\mathrm{M} * E[L i g]\right)
$$

Where $\mathrm{M}$ is the number of ligands in the cluster. In cases where the ligand has an unpaired electron and is therefore not stable as a radical (i.e. $\mathrm{Cl}$ ), the hydrogenated version of the ligand was used to calculated E[Lig] and the LBE was calculated with the following modified version of the above equation. 


$$
L B E=\left(E\left[C o_{\mathrm{N}}(\mathrm{Lig})_{\mathrm{M}}\right]+\frac{M}{2} * E\left[\mathrm{H}_{2}\right]\right)-\left(E\left[\mathrm{Co}_{\mathrm{N}}\right]+\mathrm{M} * E[\mathrm{Lig}]\right)
$$

\section{Calculation of total and local magnetic moments}

The local magnetic moment atom $\mathrm{i}$ is given by the following equation. ${ }^{1}$

$$
\mu_{i}=\int_{0}^{R}\left[\rho_{\uparrow}(r)-\rho_{\downarrow}(r)\right] d r
$$

Where $R$ is the radius of the augmentation sphere centered at atom $i$, and $\rho_{\uparrow}(r)\left(\rho_{\downarrow}(r)\right)$ is the majority (minority) spin density. The radius of the augmentation sphere in which the integration is preformed is chosen as half the bond length of the nearest neighbor bond length to ensure there is no overlap between atoms. The total magnetic moment of the system is given by the sum of each atoms local magnetic moment.

To estimate the error in the calculation of total magnetic moment we report the value of spin contamination in Table S4. The total magnetic moment is calculated as an integral of the net spin density over all space. In an unrestricted calculation, the spatial components of the spin-up and spin-down wavefunctions can be different. Spatial mismatch results in regions of space where the net spin density is negative. In DFT, spin contamination is calculated as the integral of the net spin density over all space where the spin down electron density is greater than the spin up electron density. 
Table S4. Average LBE and percentage of spin contamination for each cluster with a $\mathrm{Co}_{13}$ core.

\begin{tabular}{ccc}
\hline System & $\begin{array}{c}\text { Average LBE }(\mathrm{eV} / \\
\text { Ligand })\end{array}$ & $\begin{array}{c}\text { Spin } \\
\text { Contamination (\%) }\end{array}$ \\
\hline $\mathrm{Co}_{13}\left(\mathrm{PH}_{3}\right)_{12}$ & -1.06 & 4.1 \\
\hline $\mathrm{Co}_{13}\left(\mathrm{PH}_{3}\right)_{9} \mathrm{Cl}_{3}$ & -1.28 & 2.4 \\
\hline $\mathrm{Co}_{13}\left(\mathrm{PH}_{3}\right)_{6} \mathrm{Cl}_{6}$ & -1.44 & 1.8 \\
\hline $\mathrm{Co}_{13}\left(\mathrm{PH}_{3}\right)_{3} \mathrm{Cl}_{9}$ & -1.50 & 1.7 \\
\hline $\mathrm{Co}_{13} \mathrm{Cl}_{12}$ & -1.43 & 2.5 \\
\hline $\mathrm{Co}_{13} \mathrm{~F}_{12}$ & -0.87 & 2.2 \\
\hline $\mathrm{Co}_{13} \mathrm{Br}_{12}$ & -1.62 & 3.2 \\
\hline $\mathrm{Co}_{13}(\mathrm{OH})_{12}$ & -0.70 & 2.7 \\
\hline $\mathrm{Co}_{13}(\mathrm{CO})_{12}$ & -1.35 & 2.2 \\
\hline $\mathrm{Co}_{13}\left(\mathrm{NH}_{3}\right)_{12}$ & -0.64 & 4.5 \\
\hline $\mathrm{Co}_{13}(\mathrm{PCl})_{12}$ & -1.04 & 3.7 \\
\hline
\end{tabular}




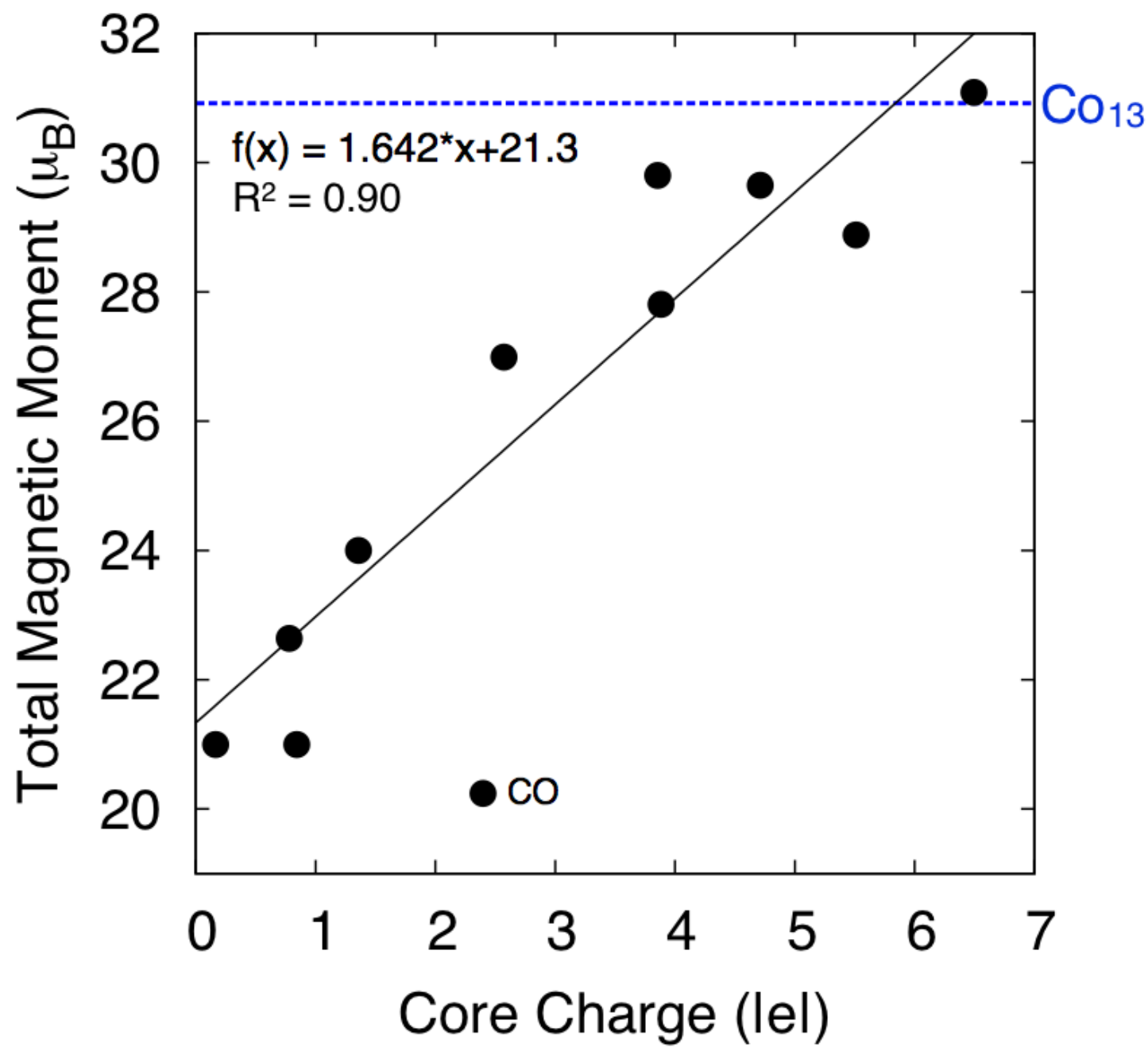

Figure S1. Total magnetic moment vs. core charge for each system with a $\mathrm{Co}_{13}$ core, linear regression was preformed excluding the $\mathrm{CO}$ ligand system. 
Table S5. Average Bader charge and average LMM on each ligand passivating a $\mathrm{Co}_{13}$ core.

\begin{tabular}{ccc}
\hline System & $\begin{array}{c}\text { Ligand Charge } \\
(\mid \mathrm{e} / / \text { ligand })\end{array}$ & $\begin{array}{c}\text { Ligand Magnetic } \\
\text { Moment } \\
\left(\mu_{\mathrm{B}} / \text { ligand }\right)\end{array}$ \\
\hline $\mathrm{Co}_{13}\left(\mathrm{PH}_{3}\right)_{12}$ & -0.01 & 0.00 \\
\hline $\mathrm{Co}_{13}\left(\mathrm{PH}_{3}\right)_{9} \mathrm{Cl}_{3}$ & -0.11 & 0.02 \\
\hline $\mathrm{Co}_{13}\left(\mathrm{PH}_{3}\right)_{6} \mathrm{Cl}_{6}$ & -0.21 & 0.04 \\
\hline $\mathrm{Co}_{13}\left(\mathrm{PH}_{3}\right)_{3} \mathrm{Cl}_{9}$ & -0.32 & 0.08 \\
\hline $\mathrm{Co}_{13} \mathrm{Cl}_{12}$ & -0.39 & 0.12 \\
\hline $\mathrm{Co}_{13} \mathrm{~F}_{12}$ & -0.54 & 0.18 \\
\hline $\mathrm{Co}_{13} \mathrm{Br}_{12}$ & -0.32 & 0.11 \\
\hline $\mathrm{Co}_{13}\left(\mathrm{OH}_{12}\right.$ & -0.46 & 0.16 \\
\hline $\mathrm{Co}_{13}\left(\mathrm{CO}_{12}\right.$ & -0.20 & 0.00 \\
\hline $\mathrm{Co}_{13}\left(\mathrm{NH}_{3}\right)_{12}$ & -0.06 & 0.00 \\
\hline $\mathrm{Co}_{13}(\mathrm{PCl})_{12}$ & -0.07 & 0.00 \\
\hline
\end{tabular}




\section{Impact of ligand shell morphology on the magnetic properties of $\mathrm{Co}_{13}$ nanoclusters}

For mixed ligand systems, there are $\mathrm{N}$ choose $\mathrm{k}$ possible ways to arrange two unique ligands on the surface, where $\mathrm{N}$ is the number of total binding positions and $\mathrm{k}$ is the number of one ligand type. For example, there are 924 unique ways, not including symmetry, to arrange $6 \mathrm{PH}_{3}$ and $6 \mathrm{Cl}$ ligands on the surface of a $\mathrm{Co}_{13}$ core. To understand the impact various ligand shell morphologies has on the calculated magnetic properties, we generated three different systems with a ligand shell composition of $\left(\mathrm{PH}_{3}\right)_{6} \mathrm{Cl}_{6}$. These three systems include the randomly generated structure discussed in the main text, a 'half' system with a completely phase separated ligand shell, and a 'striped' system with a stripe of $\mathrm{PH}_{3}$ ligands around the equator of the core that separates 2 bunches of $3 \mathrm{Cl}$ ligands. Figure S2 and Table S6 show the structures and magnetic properties of these three systems respectively. Overall, there is very little deviation in the distribution of net spin density between these three systems, indicating that ligand shell composition instead of morphology is the dominant factor in determining the final magnetic properties of the nanocluster.

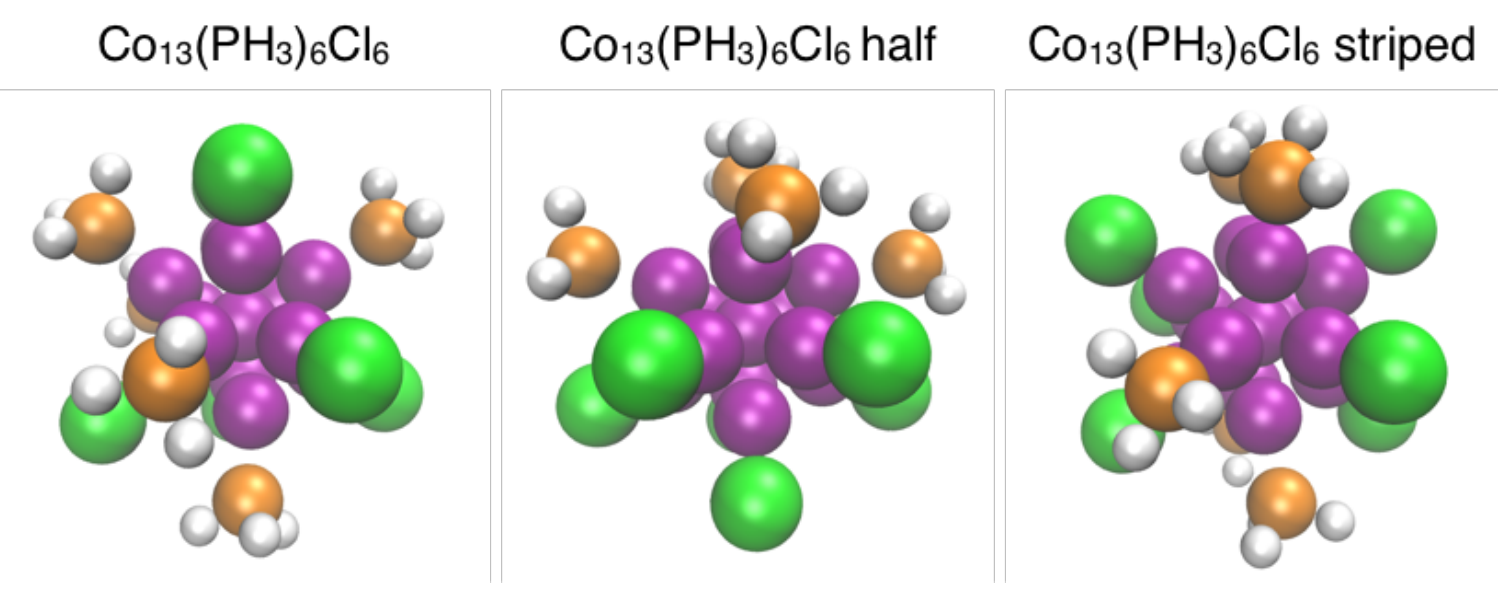

Figure S2. Structures of each ligand morphology considered with a $\left(\mathrm{PH}_{3}\right)_{6} \mathrm{Cl}_{6}$ ligand shell composition. 
Table S6. Magnetic properties and charge analysis of $\left(\mathrm{PH}_{3}\right)_{6} \mathrm{Cl}_{6}$ ligand shells with three different morphologies.

\begin{tabular}{c|cccccc}
\hline \multirow{2}{*}{ System } & \multicolumn{3}{c}{ Magnetic Properties } & \multicolumn{3}{c}{ Bader Charge } \\
\cline { 2 - 7 } & $\begin{array}{c}\text { Total Magnetic } \\
\text { Moment }\left(\mu_{\mathrm{B}}\right)\end{array}$ & $\begin{array}{c}\text { Center LMM } \\
\left(\mu_{\mathrm{B}} / \text { atom }\right)\end{array}$ & $\begin{array}{c}\text { Edge LMM }\left(\mu_{\mathrm{B}} /\right. \\
\text { atom })\end{array}$ & $\begin{array}{c}\text { Total Core } \\
\text { Charge }(|\mathrm{e}|)\end{array}$ & $\begin{array}{c}\text { Center Charge } \\
(|\mathrm{e}| / \text { atom })\end{array}$ & $\begin{array}{c}\text { Average Edge } \\
\text { Charge }(|\mathrm{e}| / \text { atom })\end{array}$ \\
\cline { 1 - 6 } $\begin{array}{c}\mathrm{Co}_{13}\left(\mathrm{PH}_{3}\right)_{6} \mathrm{Cl}_{6} \\
\text { mixed }\end{array}$ & 27.0 & 1.04 & 2.12 & 2.57 & -0.29 & 0.24 \\
\hline $\begin{array}{c}\mathrm{Co}_{13}\left(\mathrm{PH}_{3}\right)_{6} \mathrm{Cl}_{6} \\
\text { half }\end{array}$ & 27.0 & 1.02 & 2.10 & 2.60 & -0.28 & 0.24 \\
\hline $\begin{array}{c}\mathrm{Co}_{13}\left(\mathrm{PH}_{3}\right)_{6} \mathrm{Cl}_{6} \\
\text { striped }\end{array}$ & 27.0 & 0.93 & 2.12 & 2.63 & -0.29 & 0.24 \\
\hline
\end{tabular}
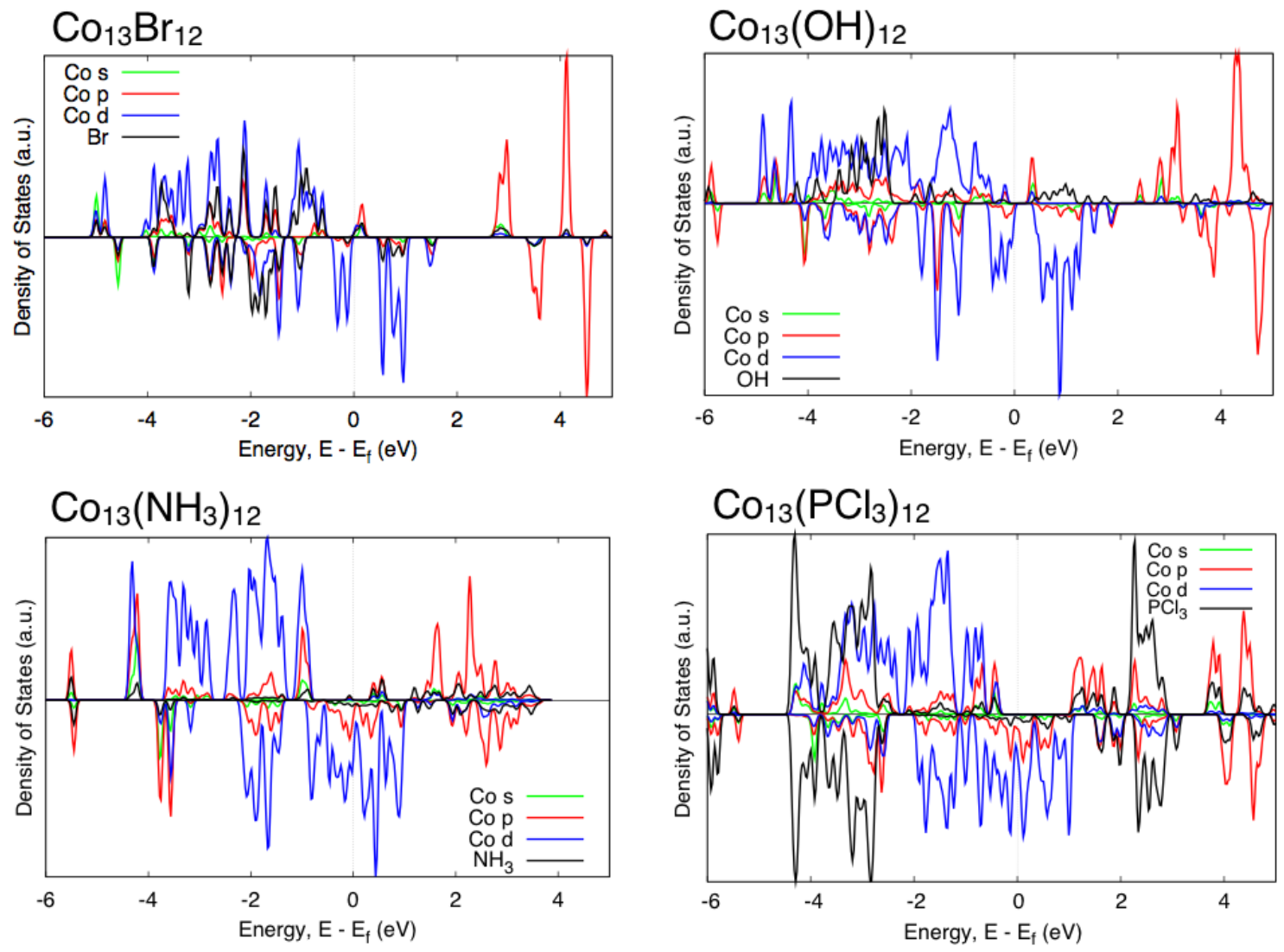

Figure S3. Projected density of states for single metal ligand bonds for $\mathrm{Co}_{13} \mathrm{Br}_{12}$, $\mathrm{Co}_{13}(\mathrm{OH})_{12}, \mathrm{Co}_{13}\left(\mathrm{NH}_{3}\right)_{12}$, and $\mathrm{Co}_{13}\left(\mathrm{PCl}_{3}\right)_{12}$ systems. Majority (minority) spin is plotted above (below) $\mathrm{x}$-axis. 

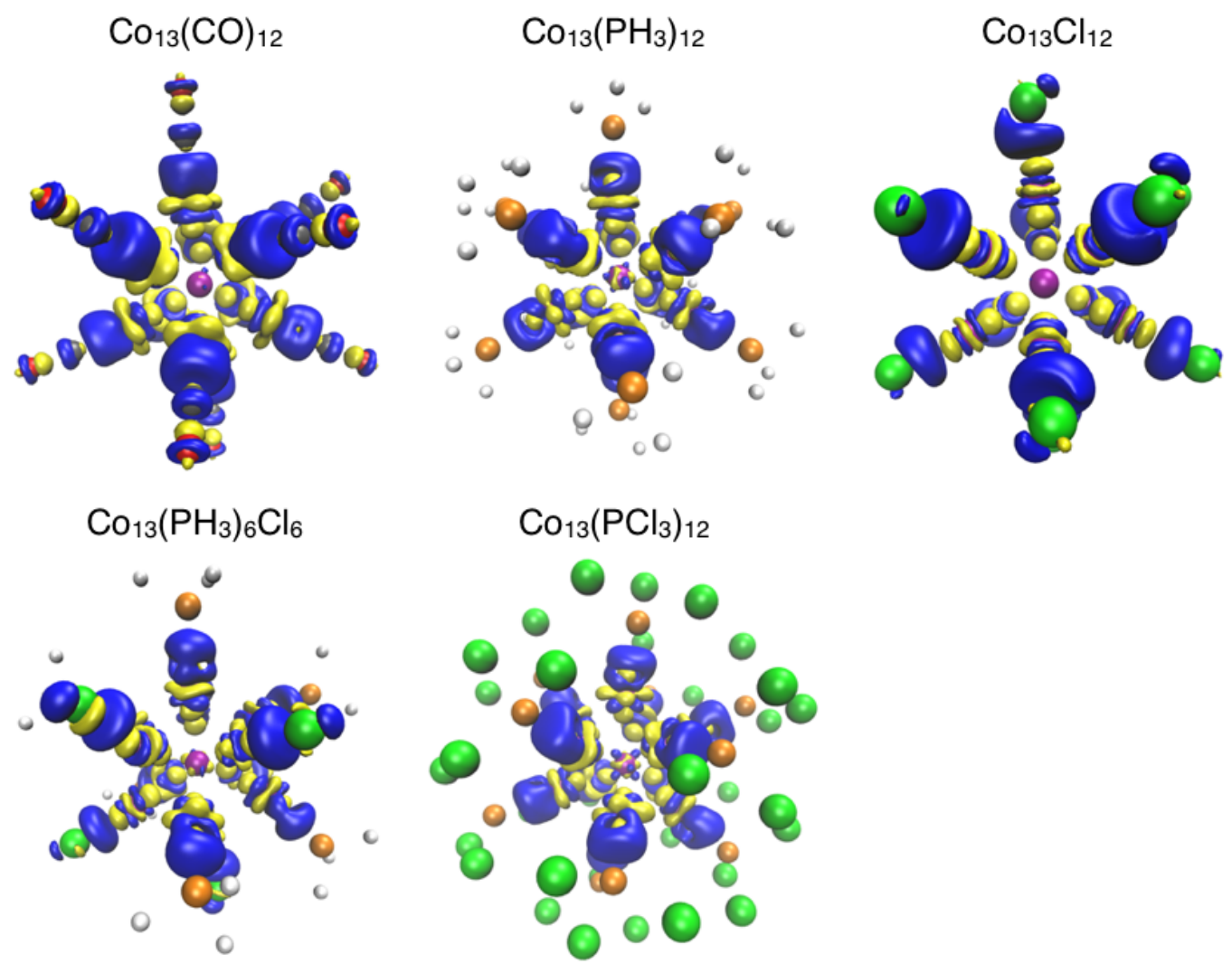

Figure S4. Isosurface plots of the difference electron density induced from the binding of various ligand shells to a $\mathrm{Co}_{13}$ core. Radial probability densities are shown in the main text (Figure 3c).

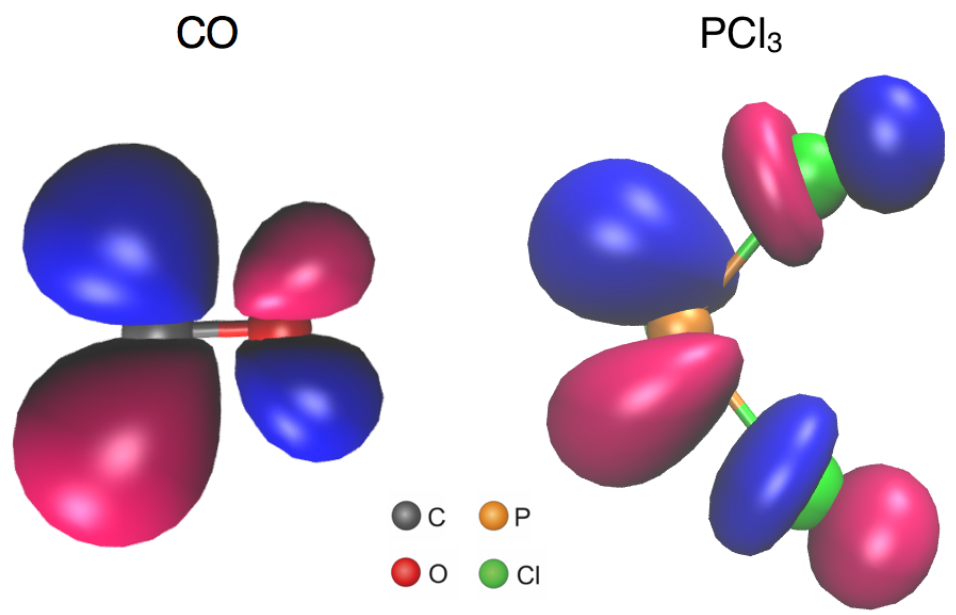

Figure S5. Isosurface plots of the orbitals that can $\pi$ back bond by accepting electron density from the metal core for $\mathrm{CO}$ and $\mathrm{PCl}_{3}$ ligands. 
Analysis of each system considered containing an icosahedral $\mathrm{Co}_{55}$ core

Table S7. Average Bader charge and average LMM on each ligand passivating a $\mathrm{Co}_{55}$ core.

\begin{tabular}{ccc}
\hline System & $\begin{array}{c}\text { Ligand Charge } \\
(|\mathrm{e}| / \text { ligand })\end{array}$ & $\begin{array}{c}\text { Ligand Magnetic } \\
\text { Moment } \\
\left(\mu_{\mathrm{B}} / \text { ligand }\right)\end{array}$ \\
\hline $\mathrm{Co}_{55}\left(\mathrm{PH}_{3}\right)_{42}$ & 0.00 & 0.00 \\
\hline $\mathrm{Co}_{55}\left(\mathrm{PH}_{3}\right)_{21} \mathrm{Cl}_{21}$ & -0.20 & 0.03 \\
\hline $\mathrm{Co}_{55} \mathrm{Cl}_{42}$ & -0.35 & 0.13 \\
\hline
\end{tabular}

Table S8. Average binding energy per ligand for each cluster with a $\mathrm{Co}_{55}$ core.

\begin{tabular}{c|c|c}
\hline System & $\begin{array}{c}\text { Average LBE }(\mathbf{e V} / \\
\text { Ligand) }\end{array}$ & $\begin{array}{c}\text { Spin Contamination } \\
\mathbf{( \% )}\end{array}$ \\
\hline $\mathrm{Co}_{55}\left(\mathrm{PH}_{3}\right)_{42}$ & -0.59 & 12.0 \\
\hline $\mathrm{Co}_{55}\left(\mathrm{PH}_{3}\right)_{21} \mathrm{Cl}_{21}$ & -0.85 & 5.2 \\
\hline $\mathrm{Co}_{55} \mathrm{Cl}_{42}$ & -0.58 & 3.5 \\
\hline
\end{tabular}

Table S9. Average Bader charge at each unique metal position in the cluster with a $\mathrm{Co}_{55}$ core.

\begin{tabular}{cccccc}
\hline System & $\begin{array}{c}\text { Total Core } \\
\text { Charge (|e|) }\end{array}$ & $\begin{array}{c}\text { Center } \\
\text { Charge }(|\mathbf{e}| / \\
\text { atom) }\end{array}$ & $\begin{array}{c}\text { Middle Shell } \\
\text { Charge (|e|l } \\
\text { atom) }\end{array}$ & $\begin{array}{c}\text { Surface Charge } \\
(|\mathbf{e}| / \text { atom })\end{array}$ \\
\hline $\mathrm{Co}_{55}$ & 0.0 & -0.15 & 0.05 & -0.01 \\
\hline $\mathrm{Co}_{55}\left(\mathrm{PH}_{3}\right)_{42}$ & -0.03 & -0.18 & -0.08 & 0.03 \\
\hline $\mathrm{Co}_{55}\left(\mathrm{PH}_{3}\right)_{21} \mathrm{Cl}_{21}$ & 8.24 & -0.15 & -0.05 & 0.21 \\
\hline $\mathrm{CO}_{55} \mathrm{Cl}_{42}$ & 14.62 & -0.12 & -0.08 & 0.37 \\
\hline
\end{tabular}


Table S10. Average bond length for four different bonds in each cluster with a $\mathrm{Co}_{55}$ core.

\begin{tabular}{ccccc}
\hline System & $\begin{array}{c}\text { Center - } \\
\text { Middle BL } \\
(\AA)\end{array}$ & $\begin{array}{c}\text { Middle - } \\
\text { Middle BL } \\
(\AA)\end{array}$ & $\begin{array}{c}\text { Surface - } \\
\text { Surface BL } \\
(\AA)\end{array}$ & $\begin{array}{c}\text { Surface- } \\
\text { Ligand BL } \\
(\AA)\end{array}$ \\
\hline $\mathrm{Co}_{55}$ & 2.39 & 2.51 & 2.49 & - \\
\hline $\mathrm{Co}_{55}\left(\mathrm{PH}_{3}\right)_{42}$ & 2.38 & 2.50 & 2.51 & 2.14 \\
\hline $\mathrm{Co}_{55}\left(\mathrm{PH}_{3}\right)_{21} \mathrm{Cl}_{21}$ & 2.37 & 2.50 & 2.53 & 2.22 \\
\hline $\mathrm{Co}_{55} \mathrm{Cl}_{42}$ & 2.37 & 2.49 & 2.54 & 2.09 \\
\hline
\end{tabular}

\section{References}

1. Ganguly, S.; Kabir, M.; Datta, S.; Sanyal, B.; Mookerjee, A., Magnetism in small bimetallic Mn-Co clusters. Phys. Rev. B 2008, 78, 014402. 